\title{
Hidrolisis Ampas Biji Sorgum dengan Microwave untuk Produksi Gula Pereduksi sebagai Bahan Baku Bioetanol
}

\section{Sefrinus M. D. Kolo ${ }^{\mathrm{a}}$, dan Eduardus Edi ${ }^{\mathrm{b}}$}

${ }^{a}$ Program Studi Kimia, Universitas Timor, Kefamenanu, TTU-NTT, Indonesia, email: sefriunimor@gmail.com

${ }^{b}$ Program Studi Kimia, Universitas Timor, Kefamenanu, TTU- NTT, Indonesia, email: edieduardus@gmail.com

\section{Article Info}

\section{Article history:}

Received 13 Desember 2018

Received in revised form 17 Desember 2018

Accepted 20 Desember 2018

DOI:

https://doi.org/10.32938/slk.v1i2.596

Keywords:

Sorgum, Hidrolisis, Microwave, Gula

Pereduksi, Bioetanol

\section{Abstrak}

Sorgum merupakan tanaman serealia yang dapat tumbuh pada berbagai keadaan lingkungan sehingga potensial dikembangkan, khususn ya pada lahan marginal beriklim kering di Indonesia. Sorgum manis mempunyai potensi yang besar digunakan sebagai bahan baku etanol selain tebu. Budidaya sorgum manis mengalami pergeseran dari bahan baku pangan dan pakan menjadi bahan baku industri, baik skala kecil maupun skala besar. Penelitian ini bertujuan untuk mendapatkan kadar gula pereduksi sebagai bahan baku bioethanol melalu hidrolisis menggunakan microwave. Sebanyak 10 gram serbuk sorgum disuspensi dengan larutan $\mathrm{H}_{2} \mathrm{SO}_{4}$ encer $0,1 \mathrm{~N}, 0,3 \mathrm{~N}$ dan $0,5 \mathrm{~N}$ sebanyak $250 \mathrm{~mL}$ lalu dipanaskan menggunakan iradiasi microwave pada temperatur $200{ }^{\circ} \mathrm{C}$ selama 20 dan 40 menit. Fraksi cair hasil hidrolisis dianalisis kandungan gula pereduksi dengan metode DNS menggunakan spektrofotometer UV-Vis. Hasil yang diperoleh menunjukkan bahwa kondisi optimum hidrolisis menggunakan microwave dicapai pada konsentrasi $\mathrm{H}_{2} \mathrm{SO}_{4} 0,5 \mathrm{~N}$ temperatur $200{ }^{\circ} \mathrm{C}$ dan waktu hidrolisis 40 menit. Kadar gula pereduksi sebesar $42,71 \mathrm{mg} / \mathrm{L}$. Kadar gula naik sebesar 19,95\% dibanding waktu hidrolisis 20 menit.

\section{Pendahuluan}

Kebutuhan energi saat ini merupakan salah satu permasalahan utama dunia, termasuk Indonesia. Sektor industri, transportasi dan kebutuhan rumah tangga meningkat sangat signifikan. Hal ini seiring juga dengan semakin menurunnya kemampuan produksi minyak bumi dalam negeri secara alami. Akibatnya terjadi krisis energi, menipisnya cadangan sumber bahan bakar fosil (unrenewable energy), serta harga $\mathrm{BBM}$ dunia yang semakin meningkat Beberapa tahun belakangan telah dilakukan penelitian-penelitian untuk mendapatkan bahan bakar alternatif dari sumber daya alam terbarukan seperti biodiesel, bioetanol maupun biogas (Kolo $d k k$., 2016).

Penggunaan bioetanol sebagai bahan bakar memiliki prospek yang bagus karena bersifat multiguna diantaranya sebagai peningkat angka oktan, meningkatkan efisiensi pembakaran, dan sebagai sumber oksigen untuk pembakaran yang lebih bersih. Bioetanol juga mudah terurai dan aman karena tak mencemari air (Hidayati $d k k, 2016$ ). Bioetanol dapat diproduksi dari bahan baku biomassa yang mengandung gula, pati atau lignoselulosa. Beberapa contoh biomassa lignoselulosa yaitu jerami padi, ampas tebu, tongkol jagung, dan bagas sorgum serta kulit biji sorgum. Pada penelitian ini, biomassa yang hendak diteliti adalah biji sorgum. Biji sorgum mengandung $70,7 \%$ karbohidrat, $10,4 \%$ protein, 3,1\% lemak, 1,6\% abu dan 2,0\% serat kasar (Suarni, 2012).

Setelah mendapatkan kulit biji sorgum, proses selanjutnya adalah mengonversi selulosa menjadi karbohidrat sederhana (D-xilosa, D-glukosa, Dmanosa, D-galaktosa, dan L-manosa) melalui hidrolisis asam. Proses hidrolisis asam adalah proses pemutusan ikatan $\beta$ - $(1,4)$-glikosida dengan bantuan asam kuat $\left(\mathrm{H}^{+}\right)$misalnya $\mathrm{H}_{2} \mathrm{SO}_{4}$ atau $\mathrm{HCl}$. Proses hidrolisis konvensional menggunakan asam dengan konsentrasi yang tinggi, menghasilkan rendemen yang rendah, dengan waktu refluks yang lama sehingga biaya produksi mahal, limbah yang dihasilkan berdampak negatif terhadap lingkungan, dan mempercepat terjadinya korosi pada reaktor hidrolisis.

Proses hidrolisis dengan bantuan microwave menjadi suatu hal yang baru dan dapat menjawab berbagai permasalahan yang dikemukakan sebelumnya. Pada proses hidrolisis selulosa dengan asam menggunakan metode microwave, konversi langsung pati menjadi gula sederhana berlangsung dalam waktu yang relatif singkat. Dibandingkan dengan pemanasan konvensional, laju reaksi hidrolisis pati menjadi glukosa meningkat 50-100 kali dengan penggunaan iradiasi microwave (Nikolić $d k k, 2010)$. Hal ini menjadi dasar untuk mengonversi selulosa menjadi gula sederhana serta fermentasi dengan produksi bioetanol yang lebih tinggi. Konsentrasi asam yang digunakan juga lebih rendah sehingga menjadi lebih ramah lingkungan, selain menghemat biaya dan waktu produksi yang menjadi lebih pendek.

\section{Metode}

\subsection{Tempat Dan Waktu Penelitian}

Sampel ampas sorgum didapatkan dari Kabupaten Malaka, Provinsi Nusa Tenggara Timur. Penelitian ini dilaksanakan di Laboratorium Faperta Universitas Timor. Analisis Gula Pereduksi dilakukan di UPT Laboratorium UNIKA Widya Mandira Kupang.

\subsection{Rancangan Penelitian}

a. $\quad$ Pretreatment Kering

Sampel sorgum yang diambil, dikeringkan selama 24 jam lalu diblender dan dikeringkan dalam oven selama 4 jam pada temperatur $60{ }^{\circ} \mathrm{C}$. Serbuk sorgum selanjutnya digerus dan diayak dengan ayakan 100 mesh.

\section{b. Pretreatment Basah}

Hidrolisis asam encer dengan Microwave. Metode hidrolisis dengan microwave dikembangkan dari Kumar (2009). Hidrolisis ampas biji sorgum menggunakan microwave dilakukan dengan menimbang sebanyak 10 gram serbuk sorgum disuspensi dengan larutan $\mathrm{H}_{2} \mathrm{SO}_{4} 0,1 \mathrm{~N}, 0,3 \mathrm{~N}, 0,5 \mathrm{~N}$ sebanyak $250 \mathrm{~mL}$ lalu dipanaskan menggunakan iradiasi microwave di dalam reaktor microwave pada temperatur $200{ }^{\circ} \mathrm{C}$ selama 20 dan 40 menit. Hasil hidrolisis disaring lalu dinetralkan untuk proses selanjutnya. Fraksi cair dianalisis kandungan gula pereduksi dengan metode DNS menggunakan spektrofotometer UV-Vis.

c. Analisis Gula Pereduksi

Jumlah gula pereduksi ditentukan dengan metode asam3,5-dinitrosalisilat (DNS) dan glukosa ditentukan dengan menggunakan kitoksidase/peroksidase dari Bio Systems. Penentuan ini dikembangkan oleh Bintang (2010). Prosedur: Larutan glukosa standar dibuat dengan konsentrasi masing-masing 0, 200, 400, 800, 1200, 1600 dan 2000 ppm. Masing-masing larutan diambil $1 \mathrm{~mL}$, lalu ditambahkan $3 \mathrm{~mL}$ pereaksi DNS. Kemudian, masing-masing larutan divorteks dan dipanaskan dalam air mendidih selama 5 menit. Setelah dingin, masingmasing larutan diencerkan 5 kali dan divorteks kembali. Absorbannya diukur dengan spektrofotometer pada panjang gelombang $540 \mathrm{~nm}$, kemudian dibuat persamaan linear sebagai kurva standar. Pengukuran kadar gula pereduksi pada sampel dilakukan dengan cara mengambil $1 \mathrm{~mL}$ sampel kemudian ditambahkan $3 \mathrm{~mL}$ pereaksi DNS. Proses selanjutnya sama seperti pada larutan glukosa standar, kemudian nilai pengukuran yang diperoleh diplot pada kurva standar.

\section{Hasil dan Pembahasan \\ 3.1 Pengambilan Sampel}

Saat ini biji sorgum yang dipakai sebagai sampel dalam penelitian ini sudah sangat sulit untuk didapatkan karena tanaman ini sudah jarang dibudidayakan lagi karena masyarakat lebih memilih nasi sebagai makanan pokok setiap hari. Biji sorgum dalam penelitian ini didapatkan dari Manlea, Kabupaten Malaka.

\subsection{Pretreatment Kering}

Sampel sorgum yang sudah didapatkan, selanjutnya dipakai untuk penelitian dengan perlakuan pendahuluan yakni Pretreatment Kering. Pretreatment dilakukan dengan cara, biji sorgum dijemur selama 24 jam di bawah panas matahari. Selanjutnya dihancurkan dan diayak dengan ayakan 100 mesh dengan tujuan mendapatkan serbuk dengan ukuran yang sama.

Tujuan penghancuran dan pengayakan sorgum menjadi serbuk yakni untuk memperluas permukaan bahan atau sampel sorgum sehingga memudahkan saat proses hidrolisis. Proton dari asam akan berinteraksi secara cepat dengan ikatan glikosidik oksigen pada dua unit gula sehingga akan membentuk asam konjugasi. Keberadaan asam konjugasi menyebabkan konformasi tidak stabil sehingga terjadi pemutusan ikatan C-O dan membebaskan asam konjugasi pada konformasi yang tidak stabil. Keberadaan air pada sistem akan menyebabkan $\mathrm{OH}^{-}$dari air berikatan dengan ion karbonium sehingga membebaskan gula dan proton. Proton yang terbentuk akan berinteraksi secara cepat dengan ikatan glikosidik oksigen pada dua unit gula yang lain. Proses tersebut terjadi secara kontinyu sampai semua molekul selulosa terhidrolisis menjadi glukosa (Xiang $d k k, 2003)$.

\subsection{Hidrolisis Ampas Biji Sorgum dengan Microwave}

Hidrolisis ampas biji sorgum menggunakan microwave dilakukan dengan memvariasikan waktu hidrolisis yakni 20 menit dan 40 menit dengan variasi konsentrasi $\mathrm{H}_{2} \mathrm{SO}_{4}$ yaitu $0,1 \mathrm{~N}, 0,3 \mathrm{~N}, 0,5 \mathrm{~N}$. Pemanasan dilakukan pada temperatur $200{ }^{\circ} \mathrm{C}$.

Kondisi untuk optimasi hidrolisis I dilakukan dengan cara melakukan variasi konsentrasi $\mathrm{H}_{2} \mathrm{SO}_{4}$ yaitu $0,1 \mathrm{~N}, 0,3 \mathrm{~N}, 0,5 \mathrm{~N}$. Pemanasan dilakukan pada temperatur $200^{\circ} \mathrm{C}$, dengan selama 20 menit. Hasil hidrolisis dapat menunjukkan bahwa semakin tinggi konsentrasi maka semakin pekat warna hidrolisat. Hasil optimasi proses hidrolisis ditampilkan pada Gambar 1.

Berdasarkan hasil hidrolisis dengan optimasi I yang ditampilkan pada Gambar 1. terlihat bahwa semakin tinggi konsentrasi asam sulfat yang digunakan pada proses hidrolisis, maka konsentrasi gula pereduksi yang dihasilkan semakin meningkat pula. Konsentrasi gula pereduksi tertinggi yang dihasilkan pada proses hidrolisis I adalah $8,52 \mathrm{mg} / \mathrm{L}$ pada konsentrasi $\mathrm{H}_{2} \mathrm{SO}_{4} 0,5 \mathrm{~N}$. Walaupun kadar gula pereduksi optimum diperoleh pada konsentrasi $\mathrm{H}_{2} \mathrm{SO}_{4} \mathrm{~N}$, namun konsentrasi $\mathrm{H}_{2} \mathrm{SO}_{4} 0,3 \mathrm{~N}$ yang digunakan lebih baik pada optimasi hidrolisis karena perbedaan kadar gula pereduksi yang dihasilkan dari kedua konsentrasi asam tersebut tidak berbeda secara signifikan. Selain itu, pengurangan 
konsentrasi asam juga dapat mengurangi penggunaan zat berbahaya selain dalam rangka penghematan penggunaan reagen kimia.

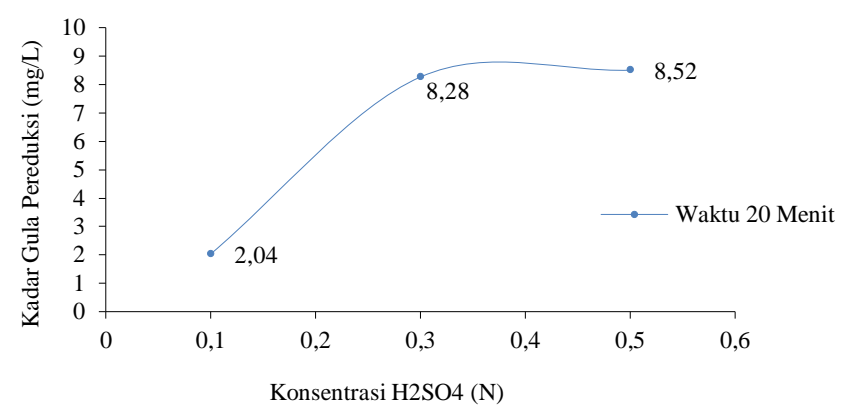

Gambar 1. Pengaruh Konsentrasi $\mathrm{H}_{2} \mathrm{SO}_{4}$ dalam Proses Hidrolisis Ampas Biji Sorgum terhadap Perolehan Gula Pereduksi (mg/L)

Kondisi untuk optimasi hidrolisis II dilakukan dengan cara melakukan variasi konsentrasi $\mathrm{H}_{2} \mathrm{SO}_{4}$ yaitu $0,1 \mathrm{~N}, 0,3 \mathrm{~N}, 0,5 \mathrm{~N}(\mathrm{v} / \mathrm{v})$. Pemanasan dilakukan pada temperatur $200{ }^{\circ} \mathrm{C}$, dengan selama 40 menit. Hasil hidrolisis menunjukkan bahwa semakin tinggi konsentrasi maka semakin pekat warna hidrolisat.

Hasil uji gula pereduksi pada optimasi ini dapat dilihat pada Gambar 2.

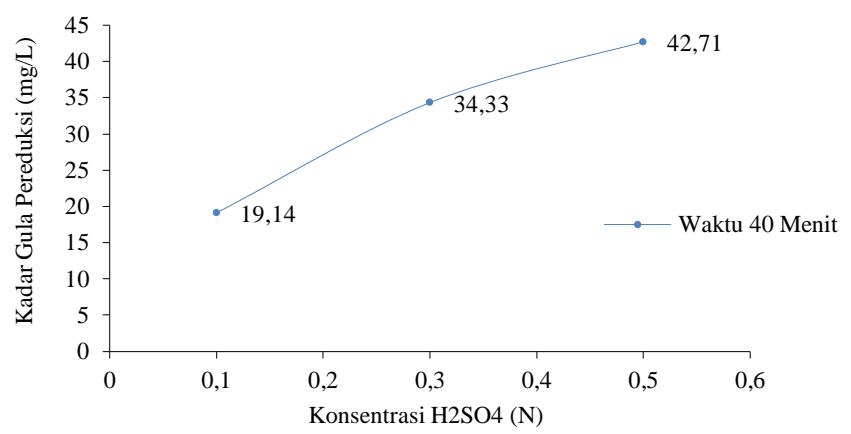

Gambar 2. Pengaruh Konsentrasi $\mathrm{H}_{2} \mathrm{SO}_{4}$ dalam Proses Hidrolisis Ampas Biji Sorgum terhadap Perolehan Gula Pereduksi (mg/L)

Berdasarkan hasil hidrolisis dengan optimasi II yang ditampilkan pada Gambar 2. terlihat bahwa kadar gula pereduksi meningkat seiring lamanya waktu hidrolisis dan semakin tinggi konsentrasi $\mathrm{H}_{2} \mathrm{SO}_{4}$. Hasil analisis DNS (Dinitrosalisilat) menunjukkan bahwa konsentrasi gula pereduksi tertinggi adalah $42,71 \mathrm{mg} / \mathrm{L}$ ketika proses hidrolisis dilakukan selama 40 menit. Waktu optimum yang menghasilkan konsentrasi gula pereduksi optimal tersebut kemudian dipakai untuk optimasi temperatur hidrolisis.

Metode penentuan gula pereduksi dalam sampel menggunakan pereaksi asam dinitro salisilat/3,5-dinitrosalicylic acid (DNS) adalah metode kimiawi. DNS memiliki senyawa aromatis yang akan bereaksi dengan gula reduksi untuk membentuk 3-amino-5-nitrosalicylic acid (Gambar 3.). Senyawa yang mampu menyerap dengan kuat radiasi gelombang elektromagnetik pada $540 \mathrm{~nm}$. Semakin banyak komponen pereduksi yang terdapat dalam sampel, maka akan semakin banyak pula molekul 3-amino-5-nitrosalicylic acid yang terbentuk dan mengakibatkan serapan makin tinggi (Leo $d k k ., 2009$ ).<smiles>O=C(O)c1cc([N+](=O)[O-])cc([N+](=O)[O-])c1O</smiles>

3,5-dinitrosalicylic acid(DNS)

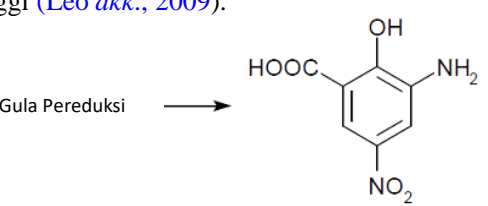

3-amino-5-nitro salicylic acid
Gambar 3. Reaksi antar Reagen DNS dan Gula Pereduksi

Reaksi dengan DNS merupakan reaksi redoks pada gugus aldehid gula dan teroksidasi menjadi gugus karboksil. DNS sebagai oksidator akan tereduksi membentuk 3-amino-5-nitrosalicylic acid. Reaksi berjalan dalam suasana basa, apabila terdapat gula reduksi pada sampel, maka larutan akan berubah dari warna kuning menjadi warna jingga kemerahan (Gambar 4.).

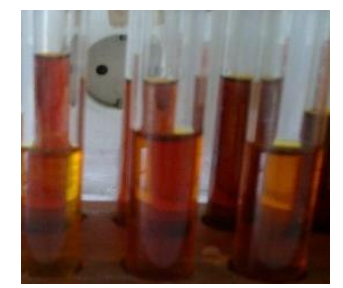

Gambar 4. Perubahan Warna Akibat Reaksi DNS dan Gula Pereduksi
Proses hidrolisis menggunakan asam sulfat dengan konsentrasi yang rendah akan menghasilkan rendemen glukosa hingga $50 \%$ dalam waktu yang cukup singkat (Xiang $d k k, 2003$ ). Rendahnya rendemen glukosa ini disebabkan oleh adanya degradasi gula hasil hidrolisis yang terbentuk karena temperatur reaksi yang digunakan sangat tinggi. Temperatur yang dibutuhkan adalah mencapai $200{ }^{\circ} \mathrm{C}$. Degradasi gula tersebut tidak hanya menurunkan konversi reaksi, namun juga dapat meracuni mikroorganisme pada saat reaksi fermentasi pada pembentukan etanol.

Pemanasan dengan bantuan iradiasi microwave dapat digunakan secara langsung dalam reaksi hidrolisis asam encer untuk konversi biomassa berpati menjadi etanol. Rendahnya waktu kontak dan konsumsi energi pada saat operasi reaksi microwave, akan menurunkan pembentukan produk sekunder yang tidak diinginkan. Pemanasan dengan microwave dapat mengonversi langsung pati menjadi gula dalam waktu yang relatif rendah. Dibandingkan dengan pemanasan konvensional, laju reaksi hidrolisis pati menjadi glukosa meningkat 100 kali dengan penggunaan iradiasi microwave (Nikolić $d k k, 2010)$.

\section{Simpulan}

Berdasarkan hasil penelitian ini dapat disimpulkan bahwa kondisi optimum hidrolisis dengan metode bantuan microwave dicapai pada konsentrasi $\mathrm{H}_{2} \mathrm{SO}_{4} 0,5 \mathrm{~N}$ temperatur $200{ }^{\circ} \mathrm{C}$ dan waktu hidrolisis 40 menit. Kadar gula pereduksi sebesar $42,71 \mathrm{mg} / \mathrm{L}$. Kadar gula naik sebesar $19,95 \%$ dibanding waktu hidrolisis 20 menit.

\section{Pustaka}

Bintang, M. 2010. Teknik Penelitian Biokimia. Departemen Biokimia, Fakultas Matematika dan Ilmu Pengetahuan Alam, IPB. Bogor. Indonesia

Hidayati, R.M., Qudsi P., Wicakso, D.R. 2016. Hidrolisis Enzimatis Sampah Buah-buahan menjadi Glukosa sebagai Bahan Baku Bioetanol. Jurnal Konversi. 5(1) pp. 18-21.

Kolo, S.M.D., Siburian, R.A.F., Lulan, T.Y.K. 2016. Produksi Biodiesel dari Minyak Biji Jarak Pagar (Jatropha curcas L.). Bio-Edu. 1(1): 6-8.

Kumar, P., Barret D.M., Delwiche, J., Stroeve, P. 2009. Methods for Pretreatment of Lignocellulosic Biomass for Efficient Hydrolysis and Biofuel Production. Journal of American Chemical Society. 48(8): 3713 3729 .

Leo M.L. Nollet, Toldra F. 2009. Handbook of Dairy Foods Analysis. CRC Press

Nikolić. S., Mojović.L., Rakin.M., Sekulić.M.V., Pejin. D., Pejin. J. 2010. Improvement of Bioethanol Production from Corn by Ultrasound and Microwave Pretreatments. Chemical Engineering Transactions 21, 13271332.

Suarni. 2012. Potensi Sorgum sebagai Bahan Pangan Fungsional Suarni. Iptek Tanaman Pangan 7(1) pp (58-66)

Xiang, Q., Lee, Y. Y., Pettersson, P. O., Torget, R. W. 2003. Heterogeneous Aspects of Acid Hydrolysis of $\alpha$-Cellulose. Biotechnology For Fuels Anc Chemicals. Applied Biochemistry and Biotechnology. 107(1-3): 505-514. 